\title{
En route for Nobility and Superiority: Preserving Indigenous Cultural Inheritances and Sustaining Competitive World Music
}

\author{
Harriman Samuel Saragih \\ Business School - Management Department \\ Universitas Pelita Harapan \\ Tangerang, Indonesia \\ harriman.saragih@uph.edu
}

\begin{abstract}
Indonesia is known for its extremely rich cultural heritages from Sabang to Merauke, not exceptionally its musical inheritances including its unique music instruments, melodic patterns, scales, and harmony. However, the present pop-culture that has been greatly affected by the Westerns has gently and inevitably eroded the homegrown cultural music which essentially still needs to be conserved. World music can act as a medium in accomplishing this noble duty, while it can also make distinctive value proposition for music artists to advance sustained superiority in the market. But the main question remains, can these both traits be realized consecutively in pursuit of nobility of cultural preservation and superiority in the industry? This study aims to gain preliminary insights regarding this particular question which has been rarely discussed among previous scholars. Exploratory method will be used on this study in qualitative manner which produce two propositions at the end for further research agenda.
\end{abstract}

\section{Keywords - world music; cultural; preservation; indonesia}

\section{INTRODUCTION}

In 2010 census, Indonesia has over 1,100 categories of ethnics; the largest proportion amongst all is Javanese, accounted for $40.05 \%$ while Sundanese were $15.5 \%$ [1]. These ethnics have their particular cultures both involve tangible and intangible asset. Examples of tangible products include sculptures, architectures, medication, handicraft, and musical instruments [2] while intangible heritages include languages, dances, and music. This study believes that it is every citizen's responsibility to preserve and maintain their cultures, so that it will not be lost and eventually be swept through times. But as trends in the society - due to globalization - are highly dynamics, homegrown cultural values can become extinct in the future, if not properly managed.

This study is deliberately carried out due to the author's anxieties of Indonesian cultures' extinction. It is likely that due to massive and intense globalization of popular Western cultures in Indonesian's young generations, the indigenous legacy of Indonesian cultures will gradually be eroded. Cultures can be lost only if the societies themselves are lost [3]. On the other parts of the world, UNESCO shared the fretfulness of cultural extinction, particularly in intangible heritages, as follows,
"According to UNESCO, the importance of intangible cultural heritage is not the cultural manifestation itself but "rather the wealth of knowledge and skills that is transmitted through it from one generation to the next." [4]

UNESCO put considerable attention to the sustainability of the indigenous cultures globally. Thus, this preliminary study would be very important in the development of theory in strategic management, business and music particularly in preserving the culture through producing music that is highly competitive and marketable. As previously stated, this study is carried out due to the concern of cultural erosion, and how world music can contribute to avoid that risk, while also provide insights to music artists or producers that world music can actually create competitive advantage.

There are various methods to prevent cultural extinction such as documentation, maintenance, and revitalization [5]. A different means to accomplish cultural preservation, according to Hezel is "a genuine sense of dynamism and a readiness to adapt to a changing world" [3]. There are some institutions which have identified this issue in preserving the cultures for examples Terralingua [6], SOAS University London [7], Living Tongue [8], and UNESCO [9]. On this study, world music is proposed to be one of the methods to achieve the noble mission. This paper will discuss mainly about the world music, and how it can pursue cultural preservation and also competitiveness for artists in music industry. In the next section, brief descriptions on well-known world music artists from around the world is presented, while concerns from the Indonesian world artists will also be illustrated to strengthen the arguments regarding collective concerns by these artists vis-à-vis cultural erosion in the Indonesian society. Generally, this study will provide preliminary facts and insights to support the apprehensions in formulating the hypotheses in Indonesian market and society regarding the effect of world music to pursue cultural preservation and also competitiveness in the music industry.

\section{LITERATURE REVIEW}

By definition, world music is a unique combination of traditional and contemporary styles music [10-12]. World music is proposed to be one particular medium to achieve the 
noble goal because of its universality. Nonetheless, there are still lacking studies regarding how world music can effectively help us to preserve the culture. Some methods are proposed such as artistic engagement [13], web-based system [14], museum [15], and cultural tourism [16]. It can be seen that previous studies regarding cultural preservation have been lacking on approaches carried out by world music. Several studies are observed on this paper regarding previous articles that discussed cultural heritage preservation such as from the teaching outline article by National Park Services [17], Universiti Teknologi MARA that examined conceptual framework on preservation management [18], preserving cultural heritage and possible impacts on regional development in Izmir [19], and even game-based learning can be a medium to preserve the culture [20]. It can be determined that studies regarding world music and cultural preservation are still lacking. Furthermore, connection with market competitiveness through producing world music - particularly in Indonesia also has been lacking of comprehensions.

There are various world music artists in the world conveying traditional music instruments, languages, and tone patterns, which is combined with the contemporary music styles. Numerous famous names such as Ashwin Batish [21] with his Indian classical sitar combine the jazz and world beat, Jonathan Scales with the Trinidad steel pan that elaborates steel pan with jazz music [22], Ladysmith Black Mambazo with its South African musical tradition combined with popular music [23], Enter the Haggis with Celtic bagpipes presented with rock music combination[24]. These musicians have brought both tangible and intangible elements of local culture to be offered to the market. Indonesia also has several distinguished artists in world music such as Viky Sianipar with his Batak music compositions with taganing, hasapi [25], I Wayan Balawan [26] on guitar tapping style with jazz atmosphere combined with gamelan and kendang, Dewa Budjana with idealistic Balinese patterns [27, 28], Dwiky Dharmawan with Balinese Folksong compositions combined with jazz [29], Tesla Manaf with Mahagotra Ganesha which bring gamelan Bali to the music [30]. Each of these artists have diverse characteristics and own typical styles. Not only musical instruments, local languages also delivered in some of their compositions.

Recent studies within the last five years on the topic of world music and cultural preservation are gathered. Howard [31] on his book discuss music as intangible cultural heritage in East Asia region. Roberts [32] argues regarding the popular music and the culture of heritage. Weiss [33] problematizes the intersection of aesthetic preferences and positions on authenticity in world music. Nettl, et al. [34] discuss mainly the world music in various parts of the world such as from China, India, Middle East, and also Indonesia. Gligorijevic [35] focuses world music in terms of festivals and tourism in Serbia. Through the previous literatures, it can be seen that previous scholars that thoroughly examine the world music, cultural preservation, and competitive advantage are deficient, hence this study aims to fill the gap in this particular area.

Several Indonesian world music artists have extensively promoted indigenous cultures in their music compositions, due to their concerns in cultural protections. In an interview from Jawaban.com, Viky Sianipar clearly mentioned that he would be very content when the audiences applauded him because of the cultural music he presented, not western popular music since he has concerns for teenagers and young adults to love their own indigenous cultures, which is achieved through music [36, 37]. Balawan also collectively shared similar concerns to preserve the Indonesian culture. He believes that particularly Balinese music will not extinct because the Balinese community has consistent regeneration every six months. However, to be exist is not enough, a maestro is required, while also considering the market trends in music [26, 38]. On the other hand, Dewa Budjana also argues the ideas of crafting world music as it will result in differentiation in the market [39]. Dwiki Dharmawan, separately also supported the ideas of preserving the cultures through music [36, 40-42]. It can be seen from these insights that Indonesian artists do put serious attention on cultural conservancy. Clearly, Indonesian artists have raised the concern, not only music as a business and profit-generating, but also in pursuit of nobility, preserving the cultures through music. This distinctive characteristic carried out by the artists is estimated to result differentiation in their value proposition. Indicators in defining world music, cultural preservation and competitive advantage on this study shall be determined to provide concise and elude ambiguities. The following section will discuss the indicators for each constructs which will be followed by propositions.

\section{DISCUSSION}

Based on the brief exposition on background and literature review, two central propositions are made on this study. The theoretical framework is shown on Figure 1.

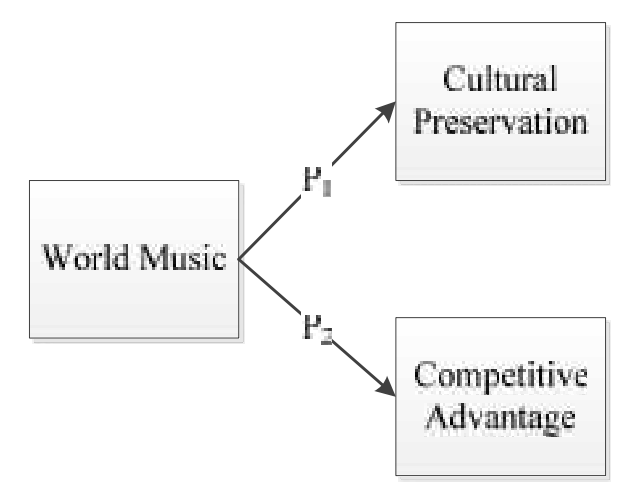

Figure 1 Theoretical Framework

World music on this study is defined as unique combination of traditional and contemporary styles music. Based on this description, we need to classify the key indicators to measure an artist that can be said to produce world music. Indicators for a composition that can be categorized as world music proposed in this study are music that contains traditional values, whether its language, melodic pattern or musical instruments - mixed with the contemporary music styles such as jazz, pop, R\&B, rock. Supplementary indicators can be included such as its indigenous attire or handcrafts. These indicators are supported by Indonesian artists mentioned in the previous section which are Viky Sianipar, Balawan, and Budjana. Viky Sianipar does utilize traditional musical instruments and Batak language [43], 
Balawan uses gamelan Bali, Balinese language and Balinese attires are worn by his team when performing live [44].

Indicators in preserving the culture are indeed required to be determined. The indicator that signals this cultural preservation is people able to understand and appreciate the indigenous values brought by the artists in presenting their music. Positive feedback submitted to world music is one of the simplest signals. Some evidences are gathered in order to see whether positive comments relate to the reviewer's tendency to, again, appreciate cultures through music.

"Thanks Vicky and the team. Over his arrangements, Batak songs have gone back in favor, at least seen again by the young generations. From my experience, a lot of friends say, "Please, Batak song?" when I was hearing Batak music. Now at least people has started to love Batak songs ... Long live Batak music. Horas ..." - Freddy Silalahi [43]

"I do not really understand Batak music ... but overall I love the song. Keep going in preserving our culture!" - Doddy Fahreza [43]

"Continue to conserve the Indonesian cultures and I hope your music gains success and well accepted in Indonesian society” Braen Arnold [43]

"Ethnic music can cultivate creativity and lift-off Indonesian cultures ... cool!" - Iyan Rief [44]

These constructive reactions show that people do actually listen and pay attention to world music, and showed that people realize the exquisiteness of the culture brought by the artist through the music. Hence, according to the above explanations, this study would like to contribute to proposition 1: World music in Indonesian music industry can work as a medium to help preserving the cultural inheritances. World music can also result in competitive advantage, particularly in Indonesia. Competitive advantage expected the world music in the Indonesian market is done through differentiation. Undeniably, in Indonesian music industry, popular music has been widely injected to the young and adult generations. This type of music is available in every crucial media station such as radio, TV, YouTube. World music is believed has and to become the 'blue ocean' in Indonesian music market. It will give fresh, distinctive, unique proposition to the market as it includes indigenous values to music listeners. Aligned with the previous explanations by Budjana [39], also Peter Tschmuck in his book "Creativity and Innovation in the Music Industry" [45], proposition 2 is: World music in Indonesian music industry can lead to competitive advantage through differentiation.

\section{SIGNIFICANCE AND CONCLUSION}

This particular review concludes that this study proposes a conceptual model that world music has the ability to preserve the cultures while also produce differentiation in the
Indonesian music industry. The aim of this study is principally to contribute preliminary comprehensions regarding the world music in Indonesia and its role for solving concerns in cultural erosion and increase competitiveness in the Indonesian music industry, of which current studies have been lacking of discussing this particular topic. Through this specific study, it is expected that future empirical study- whether qualitatively or quantitatively - can deliver practical understandings regarding the theoretical framework and contribute to the body of management knowledge.

\section{REFERENCES}

[1] B. P. Statistik. Mengulik Data Suku di Indonesia. Available: https://www.bps.go.id/KegiatanLain/view/id/127

[2] EJ-Intangible Culture-0810. A Living Legacy: Preserving Intangible Culture.

[3] F. X. Hezel. (2005). Cultural Loss: How Real is the Threat? . Available: http://www.micsem.org/pubs/counselor/frames/cult_1 ossfr.htm

[4] United Nations. (2012). Fighting cultural extinction, traditional dances and crafts added to UN list of intangible heritage. Available: http://www.un.org/apps/news/story.asp?NewsID=436 $\underline{72}$

[5] (2016). Education, Harmonious Usage and Pride. Available:

http://www.mtholyoke.edu/ alvar22n/Disappearing L anguages/Approaches to_Conservation.html

[6] (2016). There are many vital reasons why we should care. Available: http://terralingua.org/bioculturaldiversity/why-does-it-matter/

[7] SOAS. (2016). Documentation and description of endangered languages. Available: https://www.soas.ac.uk/linguistics/research/researchclusters/documentation-and-description-ofendangered-languages.html

[8] LivingTongues.org. (2016). Livingtongues.Org. Available: http://livingtongues.org/

[9] UNESCO.ORG. (2016). Best Safeguarding Practices. Available:

http://www.unesco.org/culture/ich/en/register

[10] Cambride Dictionary. (2016). Cambridge Dictionaries Online. Available: http://dictionary.cambridge.org/dictionary/english/wor ld-music

[11] (2016). Definition. Available: http://www.dictionary.com/browse/world--music

[12] Dictionary.com. (2016). Dictionary. Available: http://www.merriamwebster.com/dictionary/world\%20music

[13] V. V. Boas, "Artistic Engagement as a Way of Cultural Heritage Preservation in Rio de Janeiro," Procedia Social and Behavioral Sciences, pp. 180-186, 2015.

[14] M. Barak, O. Herscoviz, Z. Kaberman, and Y. J. Dori, "MOSAICA: A web-2.0 based system for the 
preservation and presentation," Computers \& Education, pp. 841-852, 2009.

[15] V. M. Kimeev, "Ecomuseums In Siberia As Centers For Ethnic And Cultural Heritage Preservation In The Natural Environment," Archaeology, Ethnology and Anthropology of Eurasia, vol. 35, pp. 119-128, 2008.

[16] T. Lussetyowati, "Preservation and Conservation through Cultural Heritage Tourism. Case Study: Musi Riverside Palembang," Procedia - Social and Behavioral Sciences pp. 401-406, 2015.

[17] National Park Service. (2002). Teaching Cultural Heritage Preservation [Internet].

[18] S. N. M. A. Mazlina Pati Khan, N. R. Ahmad, I. E. Khairuddin, and N. a. Ahmad-Uzir, "A Conceptual Framework on Preservation Management: Modelling the Sutstainable Development for Preserving Archival Heritage," Global Journal of Business and Social Science Review, vol. 1, 2015.

[19] E. Gunlu, K. Yagci, and I. Pirnar. Preserving Cultural Heritage and Possible Impacts on Regional Development: Case Of Izmir [Internet].

[20] Z. A. Hasibuan, Y. K.Isal, B. Anggun, M. Ahmad, and N. Selviandro, "Preservation of Cultural Heritage and Natural history through Game Based Learning," International Journal of Machine Learning and Computing, vol. 1, 2011.

[21] Ashwinbatish.com. (2016). Sitar Power - Worldbeat Raga Rock Jazz. Fusion by Ashwin Batish. Available: http://ashwinbatish.com/

[22] (2016). Steel Pan (Steel Drums) Information, Tips and Advice. Available: http://www.steelpan-steeldrumsinformation.com/steel-pan-history.html

[23] L. B. Mambazo. Our Story: Ladysmith Black Mambazo. Available: http://www.mambazo.com/our_story/

[24] Bio/Press: Enter the Haggis. Available: http://www.enterthehaggis.com/bio-press

[25] V. Sianipar, "Viky Sianipar at The Tonight Show," A. K. Untung, Ed., ed. Indonesia, 2013.

[26] N. Rodiana. (2008). Balawan: Musik Tradisional Sulit Eksis di Indonesia. Available: http://hot.detik.com/music/read/2008/12/11/102802/1 051872/228/balawan-musik-tradisional-sulit-eksis-diindonesia

[27] Dewabudjana.com. (2016). Discography. Available: http://www.dewabudjana.com/discography.php

[28] Dewa Budjana Official Website. (2016). Discography. Available: http://dewabudjana.com/discography.php

[29] M. Kita. (2014). DWIKI DHARMAWAN WPO live in USA - JANGER. Available: https://www.youtube.com/watch?v=ROg6uEaPkzI

[30] R. Kurniawan. (2014). Tesla Manaf feat Mahagotra Ganesha - It's All Yours (Reissue). Available: http://jazzuality.com/jazz-news/tesla-manaf-featmahagotra-ganesha-its-all-yours-reissue/

[31] K. Howard, Music as intangible cultural heritage: Policy, ideology, and practice in the preservation of East Asian traditions: Routledge, 2016.
[32] L. Roberts, "Talkin bout my generation: popular music and the culture of heritage," International journal of heritage studies, vol. 20, pp. 262-280, 2014.

[33] S. Weiss, "Listening to the World but Hearing Ourselves: Hybridity and Perceptions of Authenticity in World Music," Ethnomusicology, vol. 58, pp. 506$525,2014$.

[34] B. Nettl, T. Turino, I. Wong, C. Capwell, P. Bolman, B. Dueck, et al., Excursions in world music: Routledge, 2015.

[35] J. Gligorijevic, "World Music festivals and tourism: a case study of Serbia's Guca trumpet festival," International Journal of Cultural Policy, vol. 20, pp. 139-154, 2014.

[36] (2014). Viky Sianipar, Lestarikan Budaya Lewat Musik Tradisional.

Available: http://www.jawaban.com/read/article/id/2014/11/10/7 8/141110164155/Viky-Sianipar\%2C-LestarikanBudaya-Lewat-Musik-Tradisional

[37] A. Panduwinata. (2014). Viky Sianipar Ajak Anak Muda Cinta Budaya. Available: http://wartakota.tribunnews.com/2014/12/04/vikysianipar-ajak-anak-muda-cinta-budaya

[38] L. T. Pambudi. (2015). Gitaris Balawan: Musik Tradisi Bali Tidak Akan Mati, tapi... . Available: https://m.tempo.co/read/news/2015/09/04/219697738/ gitaris-balawan-musik-tradisi-bali-tidak-akan-mati$\underline{\text { tapi }}$

[39] D. Budjana, "Satu Indonesia - Dewa Budjana," M. Anita, Ed., ed, 2015.

[40] (2016). Oxford Dictionaries: Language Matters. Available:

http://www.oxforddictionaries.com/definition/english/ world-music

[41] E. Hardian. (2014). Dwiki Dharmawan Promosikan Budaya Daerah lewat Keyboard. Available: http://celebrity.okezone.com/read/2014/12/17/205/108 0517/dwiki-dharmawan-promosikan-budaya-daerahlewat-keyboard

[42] Kapanlagi.com. (2013). Dwiki Dharmawan Ajak Semua Pihak Lestarikan Budaya. Available: http://www.kapanlagi.com/showbiz/selebriti/dwikidharmawan-ajak-semua-pihak-lestarikan-budaya2134da.html

[43] V. Sianipar. (2015). Viky Sianipar Ft. Alsant Nababan Aut Boi Nian - [Official Video] Toba Dreams Soundtrack. Available: https://www.youtube.com/watch?v=V5a0muAIF60

[44] balawanguitar. (2008). Balawan \& Batuan Ethnic Fusion - The Dance of Janger. Available: https://www.youtube.com/watch?v=jmzZR_auJKI

[45] P. Tschmuck, Creativity and Innovation in the Music Industry. The Netherlands: Srpinger, 2006. 